\title{
Democratic Milestone in Pakistan: A Serener Transition of Command from PPP to PML-N
}

\author{
Muhammad Rizwan ${ }^{1}$, Rafiuddin ${ }^{2}$, Muhammad Arshid ${ }^{3}$, Muhammad Waqar ${ }^{4}$ \\ ${ }^{1,2}$ (Department of Pakistan Studies, Hazara University Mansehra, Pakistan) \\ ${ }^{3,4}$ (Department of Political Science, Hazara University Mansehra, Pakistan)
}

\begin{abstract}
Constitutional amendment. One way or the other, these reforms helped to a conduct Constitutional struggle in Pakistan took almost four decades to attain an atmosphere where a peaceful transition from one democratically elected government to another could become possible. For the first time, the government of Pakistan People's Party, under President Asif Ali Zardari, successfully completed its five years term. The PPP government, time and again, introduced a number of administrative, political and constitutional reforms including the electoral reforms, neutrality of Election Commission, consensus on caretaker government, independence of judiciary a free and fair election in 2013 resulting a nonviolent power transition to the majority party. Present study strives to dig-out the facts that made this transition of authority possible. This is an historical research; therefore, historical research method along with descriptive method is used to understand the existing phenomenon.
\end{abstract}

Keywords: Peaceful transition, Democracy, Military dictatorship, Pakistan People's Party

\section{Introduction}

It has taken almost forty years after the promulgation of 1973 Constitution to establish such a federal parliamentary system in Pakistan where a successful political transition has been witnessed. It was a changeover from one democratically elected legislature of PPP to PML-N. A glance on the political history of Pakistan clearly reveals that time to time military regimes greatly affected the democratic development in the country. They often used different tools to consolidate and stabilize their rule. Like his ancestors, President Musharraf created a system of local government with strong a Centre. He amended the 1973 Constitution and authorized himself to dissolve the National Assembly. Like Zia-ul-Haq, Musharraf was also confident on constitutional manipulation and electoral rigging.[1] Muslim League-Nawaz and Pakistan People's Party, two main political forces, although remained opponents throughout the constitutional history of the country, however, they were forcefully ejected from the political scene. King's party of Muslim League-Q was taken into the ruling corridors. Nevertheless the Prime Minister was a rubber stamp and the power was vested to the President.[2]

Both People's Party and PML-N determined to restore the parliamentary democracy in the country. Mian Muhammad Nawaz Sharif and Benazir Bhutto wanted to transfer the power from military to civilian government at any cost. They have called upon the people to join them in order to save their homeland from the clutches of a military dictator. In order to achieve said objective, they decided to defend their social and political norms of a democratic Pakistan as dreamt and wished by the founder of Pakistan in his life, and adopted the Charter of Democracy (COD).[3] Since then, the strong debates had started in Pakistan. The Charter delineated the future policy to be assumed and interpreted by the PPP and PMLN leadership regarding to ensure good governance and strengthen of democracy in the country.

\section{THE quest for democracy}

President Parvaiz Musharaf called Benazir and Nawaz Sharif's agreement as an "ironic" because Junta believed that they themselves proved as worst enemy of democracy during their term of governments. Muhammad Ali Durrani, the Information Minister, at this occasion, "Any democratic agreement can only be signed by the elected representatives of the people while they have already rejected their political adventurism."[4] However, both PPP and PML-N decided to join hands against dictatorship in order to eliminate it forever in future. They pledged to see a transformation of power from military to the elected representative of the people. With the support of civil society and other political stakeholders they adopted COD. Bothe leaders fully agreed to formulate their future strategies in the light of charter and the later events illustrated that how leadership of PPP and PML-N remained committed to their pledge.[5]

It is scholarly admitted that COD proved a constitutional landmark in the political history of Pakistan, which deals almost every aspect of the 1973 Constitution essential to revive its true spirit. These features of COD include: 
1- Original Constitution of 1973 shall be reinstated with all necessary requirements including joint electorates, minority and women recovered seats, the reduction of the voter's age and increase the number of parliamentary seats and to repeal the $17^{\text {th }}$ Constitutional amendment accordingly.

2- The selection of provincial governors, Chief Justice and three services Chiefs shell be made by the executive authority (Prime minister), as prescribed by the original Constitution.

3- In order to give more effective representation to the minorities, number of the Senate seats shall be increased.

4- With mutual consultation, FATA shell be incorporated in NWFP (presently Khyber- Pakhtunkhwa).

5- Northern region shell be treated as a special case by empowering the Legislative Council to facilitate the people for an easy justice and human rights.

6- Through Provincial Election Commissions of every respective province, the local body election, on party basis, will be held soon, and these bodies will be making answerable to people and these assemblies.

7- Complete independence for press and electronic media will be ensured.

8- The leader of Opposition would be responsible to appoint the Chairman of the Account Committee in the National and Provincial assemblies.

9- Simplicity would be practiced at all levels and the Governors would be empowered to facilitate the general people.

10- Equal opportunities would be provided to a depressed class, minorities, under privileged people or women etc.

11- Public mandate of the government would be respected; no extra constitutional measures would be taken in order to topple any representative rule or to weaken it.

12- It was solemnly pledged that no political party would ever join a military regime or any military supporter government.

13- An open identifiable voting system would be started to reduce the corruption and floor crossing.

14- All parliamentarians and senior officials including military and judicial officers would require to public their assets and declare their income to make them accountable.

15- In order to promote and widen the democratic mores, the National Democracy Commission would be formed. It would educate the political actors for their capacity building on the grounds of their representation in legislature.

16- The Prime Minister after mutual discussion with Opposition leader would put forward three names in order to choose the Chief Elections Commissioner.

17- In order to conduct free and fair elections, an unbiased caretaker government would be established while any members of caretaking setup would not be able to take part in the coming elections.

18- All political parties and personalities would be able to take part in the Elections.[6]

In the light of COD, the process for upcoming elections started. Mr. Justice Qazi Muhammad Farooq was appointed as the new Chief Election Commissioner. He, after taking over his charge, proclaimed, "The election process will start from today (Wednesday) with the Election Commission acceptation of nomination papers from November $21^{\text {st }}$ till 26 , November. The election of both the national and provincial assemblies would take place simultaneously and the final list of candidates will be published on $16^{\text {th }}$ December". [7]

the majority party with 128 seats at national level and PML-N remained the second majority party with 91 seats in the National Assembly. ${ }^{8}$ Muslim League (Q) got 19 seats; Awami National Party (ANP) won 13 seats whereas Mutahedda Majlis Amal (MMA) could secure 7 seats. Muslim League Functional (PML-F) could win 5 seats of the National Assembly. However, the independents captured including all other 18 seats. The results revealed that no party could secure an overall majority at national level. Similarly in provinces the PPP emerged the largest party in Sindh, PML-N in the Punjab, PML-Q in Balochistan and ANP in NWFP (Now Khyber Pakhtunkhwa) emerged the largest parties respectively. The elections although provided a new gateway to restore democracy in Pakistan, yet it resulted the coalition government under PPP at Center and different other political parties in provinces.[8]

\section{THE GOVERNMENT OF PAKISTAN PEOPL'S PARTY}

As a first step towards the reconciliation, as suggested by COD, both PPP and PML-N had completed their seat adjustments on different 25 constituencies of the country. It seemed that both formal rivals and Prime Ministers i.e., Benazir Bhutto and Mian Nawaz Sharif were serious enough to join their hands together for securing majority of votes with each other support. The leader of PML-N, Ishaq Dar and PPP's leader, Makhdom Amin Fahim, have played a vital role in order to create a consensus for these seat adjustments. As expected, PPP won the elections, however, did not get an absolute majority and needed to enter into a coalition with others political parties in order to form the government. Consequently, PPP have started negotiations with the PML-N that won the second most seats during the elections.[9] 
As discussed earlier, both major parties through COD determined to undo some of the constitutional changes done by the military regime of Pervez Musharraf including 13 Constitutional Amendments that permitted the President to disband the legislature and dismissed the government. Co-Chairperson of PPP Asif Ali Zardari, at this occasion said, "The party would try to form a government of consensus and taking on panel all political parties". After the ending of Central Executive Committee's meeting of the party, while addressing to a press conference in Islamabad, he said, "I will take all political parties on board including those who are out of the parliament".[10]

PML-N and People's Party, like other political forces of the country, pledged to establish a viable democratic system based on the principals of tolerance, harmony and social justice in order to strengthening the roots of democratic culture in the country and to remove every impediment which may weaken the democracy. Mr. Zardari reaffirmed his commitment by saying, "The People's Party was in comfortable position to form a stable government in Sindh, but they have desire to cooperate with MQM as well, and I also wanted to formulate my government along with the MQM" On another occasion, he told in the news conference, "I have contacted with Qazi Hussian Ahmad, Imran Khan, Mahamood Khan Achakzai and would be a meeting with Mian Muhammad Nawz Sharif the leader of Pakistan Muslim league Nawaz tomorrow". He stressed that "we want to form government but it must be one in authority."[11] Yet he refused to be a candidate for a Prime Minister's job as this matter will be consulted with other political parties. Similarly, PPP leadership also inclined to strengthen the Judiciary, empowering the Parliament, to give more autonomy to the provinces and to ensure Media independence etc. Consequently, other political parties in the Parliament also played their positive role and the Prime Ministerial contender Sayed Yousaf Raza Gilani of Pakistan People's Party, was unanimously elected. In point of fact, it was the sprite of unanimity that facilitated a viable change in the 1973 Constitution due to which the Parliament could pass a resolution to amend it.[12]

\subsection{Role of Parliamentary Committee on Constitutional Reforms (PCCR)}

After assuming authority, first step of the newly elected government of PPP was to move for the restoration of democracy and to eliminate the dictatorial changes in the Constitution of 1973. The task of amending the Constitution was allocated to the Parliamentary Committee on Constitutional Reforms (PCCR) headed by Mian Raza Rabani. This 27 members Committee anticipated about one hundred amendments covering around 75 Subjects. However, on most of proposals, PCCR adopted an undivided stance.[13] On $31^{\text {st }}$ March, 2010, the Committee approved it and Parvaiz Ashraf, Minister for Water and Power, has signed the draft. It was followed by Professor Khursheed Ahmad (JI), Syed Naveed Qamer, Aftab Ahmad Khan Sherpao (PPP-S), Baber Awan, Ishaq Dar, Lashkari Reisani (PPP), Ahmad Khan Abbasi, Abdurrazaq Taheem and Ahsan Iqbal (PML-N),Waseem Sajjad, Hamayun Saifullah (PML-Q), Dr. Farooq Sattar (MQM), Haji Muhammad Adeel (ANP), Rehmatullah Kakers (JUI), Baloch leader Mir Israrullah Zehri and Munair Khan Orakzai from FATA have signed. However, the Committee Chairman Raza Rabaani signed the draft at the very end.[14]

Elimination of Controversial Amendments

After the promulgation of a unanimous Constitution in 1973, President General Zia-ul-Haq was the first who dictatorially distorted more than 90 articles of the Constitution in $58(2) \mathrm{B}$, commonly known as $8^{\text {th }}$ amendment of 1985. By following his footsteps, General Pervez Musharraf did the same with 26 articles of the same Constitution in the shape of $17^{\text {th }}$ amendment. Both of these dictators strengthened their offices of the President against the position of existing Prime Ministers. PPP government, in order to remove the aftermath of these articles, put forwarded more than 100 amendments directly affecting 83 subjects in order to restore the original spirit of 1973 Constitution, these are as under:

$1,6,10,17,19,25,27,29,38,41,46,48,51,58,62,6370,71,73,75,89,90,91,92,99,100,101,104,105,112,116,122,129,13$ $0,131,132,139,140,142,143,144,147,149,153,154,155,16,157,160,167,168,170,171,172,175,177,193,194,198,19$ $9,200,203,209,213,215,216,218,219,221,224,226,228,232,233,234,342,343,246,260,267,268,269$ and 270.[15]

However, the most famous clauses, which had affected the augmentation of democratic culture in the country, were replaced:

1. If a person committed or tried to be committed the abrogation, subversion, suspension or holding in abeyance the Constitution of the country would be dealt the crime of high treachery.

i) The word or collaborating would be inserted instead of word abetting in the clause (2) of the Constitution; and ii) Subsequent to clause 2 revised as aforementioned, the following fresh section will be placed in; "( $2 \mathrm{~A})$ enact of treachery revealed in clause (2) never shall be endorsed by any court together with the High or Supreme Court."[16] However, it is observed that very often military takeovers or imposition of Martial Laws have been legalized by the Supreme Court or pro-military assemblies. This practice was reduced by the Eighteenth amendment through insertion of the above article. At present, the Musharraf treachery case is an outcome of this amendment and implication of article 6 of the Constitution.

Article 17, the under given are to be surrogated: 
Liberty of associations (1) under certain legal or moral limitations imposed by the Sovereign, every citizen in a state has right to structure an organization or association.

2. Each political organization and party will disclose its source of income and funding.

In section 3, of the article 29 of the Constitution, for the word "national assembly" taking place for the time in words and in brackets, every organ of the Majli-e-Shoora will be altered and following the word 'national assembly' happening for the $2^{\text {nd }}$ time the words 'and the Senate' shall be placed in. similarly, as discussed earlier, the article $58(2 \mathrm{~b})$ of President Zia-ul-Haq was revised in $17^{\text {th }}$ constitutional amendment by General Musharraf. The amendment was later on ratified by the then rubber stamp assembly allowing the President to dissolve the National Assembly without any grounds. However, the $18^{\text {th }}$ amendment not only removed the clause but also inserted a substituted for it.[17] The President's power to dissolve the National Assembly will only be confined to the advice of the Prime Minister and the legislature will be considered as dissolved at the end of forty eighty hours after the Prime Ministerial advice.[18]

This amendment also granted enough autonomy to the provinces by altering $70,142,143,144,149$, $157,160,161,167,172,232,233$ and 234 clauses of the Constitution. These articles empowered the provinces to deal with the affairs of electricity and natural gas and see the National Finance Commission dealings by borrowing legislative powers. However, the most important article which has given more autonomy to provinces was articled 142 (b) and (c) allowing provincial assemblies to make laws with respect of criminal, procedure, and evidence. Likewise article 270AA offered that all contemporary laws will remain in practice until, the amendment replace them by law of province. ${ }^{21}$ The eighteenth constitutional amendment, in one way or the other, amended articles 46, 48, 75, 90, 91, 99, 101, 105, 116, 129, 130, 131, 139, 231 and 243 in order to restore the parliamentary democracy with some major or minor modification.[19]

The collaboration and cooperation, on more viable basis, between People's Party and PML-N started after the assassination of Benazir Bhutto on 27 December 2007 in a terrorist attack. Both parties cooperated each other on all major legislations, including amendments in the constitution to strengthen the parliamentary democracy in Pakistan. The thirteenth National Assembly established not less than 34 standing committees ${ }^{19}$ In order to remove public grievances related to their day to day routine work. These committees were authorized to hold public hearings and consult expert openion. In fact, due to their positive alliance; the democratic role of the National Assembly could become possible. They successfully strengthened the office of the Prime Minister, the true representative of the people. Previously he was bound by the article 46 to inform the President before taking any decision. Similarly, the President's power to ask for re-examination of certain pronouncements of the cabinet was again curtailed by the $18^{\text {th }}$ amendment. Article 48 that had empowered the President to hold referendum on any important issues was again bound to get approval of the Prime Minister before holding the referendum. In point of fact; power struggle between Prime Minster and the President often clogged the permanence of the democratic process in Pakistan. Presently, by reducing powers of the Presidency up to the constitutional limits, the amendment has helped to revive the original spirit of the Constitution of 1973.[20]

\section{PREPARED FOR TRANSITION}

\section{A. Electoral Reforms}

After Pakistan People Party assumed power in 2008. It was need at the time extensive reform to the electoral system that the next election to be free and fair. The $18^{\text {th }}$ amendment introduced some reforms to the electoral system of Pakistan. It gave a role to opposition political parties representative in the appointment of chief electoral commissioner of Pakistan, by requiring the appointee must first be approved by parliamentary committee following a confirmation hearing and the member of the election commission of Pakistan (ECP). It is required that the chief election commissioner of Pakistan must be serving or retired High Court Judge. The tenure increased from three to five years. The measures following from the eighteenth amendment were consequently brought in to law by Election Laws Act in May 2011.[21]

Potentially no law important for the reliability of the future elections were measuring to strengthen the credibility of neutral caretaker government that will govern at both federal and provincial levels during 90 days (election period) which follow the dissolution of both National and Provincial assemblies. Under the eighteenth amendment the president must consult with outgoing Prime Minister and the leader of opposition on the appointment of the caretaker government. Same will be applied in the provinces. The $20^{\text {th }}$ amendment provides that if the political parties cannot agree that who should lead this government, the final decision will be passed to the Election Commission of Pakistan (ECP). A 2011 democracy reporting international (DRI) report identified the issues which were needed attention to implement reforms before the 2013 elections. They included

"Disallowing the candidacy in more than one constituency in a given election, clarifying the identification requirement for registering and voting in an election, improving the procedure for tabularize votes and publishing election results, introducing effective remedies for electoral disputes resolution and unifying election laws to increase transparency and understanding of the Legal Framework."[22] 
Chief Justice Iftikhar Muhammad Chouhdry scathingly described the election commission as "useless and defunct." But other observers defied that the performance of the Election Commission of Pakistan has greatly improved since 2008. The Supreme Court directed that voting should be made compulsory; the existing "first past the post' system should be revised. The establishing of offices near polling station by candidate should be forbidden and candidate also should not be provided transportation for voters.[23]

The political class people were worried by requiring for the candidates to submit affidavit that they do not hold dual citizen ship. According to this rule of the Supreme Court some members were disqualified from the offices on the ground that they were dual nationals. The Election Commission had also put great pressure on elected members than it past to assert their assets. Numerous members were suspended if they failed to fulfill this requirements. There has been no progress on revising constituent boundaries. The election commission said in mid 2012, the upcoming election would be held under existing boundaries. The election commission had set a target voter turnout $70 \%$ in the election. It had said that it aim to complete all arrangement for the coming election by the end of 2012 .

Justice (R) Fakhruddin G. Ibrahim was appointed as Chief Election Commissioner (CEC) of Pakistan with the consensus of all major political parties. Justice Ibrahim is a great jurist who was the judge of superior court. He had also served as law minister and Attorney General of Pakistan and also governor of Sindh. The power of Election Commission enhanced against previous ECP and made it more independent. The election commission amended the candidate's nomination papers including ownership of company; tax related information, foreign trips and children studying in abroad coupled with expense on their education, to add more credencials. ${ }^{41}$ The election commission also decided to place the nomination papers on websites so voters can be keep will informed and enabled to lift any question to ECP. Furthermore, for voters to identify their status, SMS (short message service) and website service had also been employed by Election Commission of Pakistan.[24]

\section{B. Caretaker Government}

In order to create a favourable environment for conducting free and fair elections, an independent and impartial caretaker cabinet, is a constitutional pre requisite in Pakistan. It ensures the impartiality during the elections and then transfer of power to the newly elected representatives of the people. The caretaker as a non adherent government management primarily role is to ensuring the scheduled function of government. In most of the countries once the Parliament has been dissolved the government in power change to "caretaker modus" but in Pakistan the non-elected persons are selected to structure a concierge cabinet.[25] PPP government through, the $18^{\text {th }}$ Constitutional amendment, signifies the importance of caretaker governance in Pakistan.

This amendment advocates the neutrality, impartiality and fair appointment procedure for a caretaker government's personals. In the light of legislation, the election code of conduct was in print before the commencement of 2013 General Elections. The Election Commission of Pakistan, with the assistance of neutral caretaker setup, provided decorum for all political parties and the candidates who were contesting the elections. The Commission prohibited the government official to take part in the campaign. Subsequent to the Supreme Court's verdict, Pakistani authorities can reinforce this institution by defining the errands of the caretaker administration within the Legal Framework. However, it could only be guaranteed through amending the Constitution in order to set out the jurisdictions of caretaker authorities. In point of fact, the caretaker setup is established to facilitate the citizens to take part in elections in order to have a suitable system of government to run the state affairs. Talking about political rights of the citizens, the International Convention for Civil and Political Rights (ICCPR) points out, "Political clout of any government is depending upon the rights of every citizen to take part in state affairs including the right to be elected or to vote etc."[26]

The Constitution determined the timeframe and the procedure for appointment of caretaker government. However, no legislation on functions and directives of the provincial government was available leading the judiciary to describe the confines, power and functions of the caretaker government in Pakistan.

The Constitutional amendments, during the prior legislatures, have been affected the appointment mechanism of the caretaker government. Presently, $18^{\text {th }}$ amendment provided the sub article (1a) and (1b) to the article 224 . The article 224 (1a) takes away the Presidential prudence and extended the right to join in the selection of the caretaker Prime Minister, with the consultation of Prime Minister and opposition leader in the expiring National Assembly. Similarly, article 224 (1b) provides that any member of the caretaker cabinet, including Prime Minister of Chief Minister, his wife and children etc are not eligible to take part in the elections under their supervision. These amendments also empowered the Legislature to appoint the caretaker setup in case the Prime Minister or the Opposition leader may not agree on the names and their portfolios in the caretaker government. After their appointments, the provincial and federal caretaker cabinets are formed on the recommendations of caretaker Chief Minister of the respective province and the Prime Minister.

In order to ensure neutrality during the election process, the Election Commission provided a 'Code of Conduct' for all political parties and participating candidates. The Conduct offer, "All high office bearers including President, Prime Minister, Chairman Senate, Deputy Chairman, Speaker of National Assembly, 
Deputy Speaker, Federal or State Minister etc shall not be able to participate in election campaign". Thus, the amendments provided an appropriate structure for an Interim setup to conduct a free and fair elections.

\section{General Elections 2013 and Power Transition to PML-N}

Ultimately, as per scheduled, the General Elections took place in May 2013. It has been reported that the Election Commission of Pakistan with the help of Asian International Foundation for Election Systems tried their best to hold the elections up to the international standard that enhanced the possibility of a democratic transition of power to the majority party in rightful way. Although, it was visualizing in pre-election instance that there might be rigging or manipulation of results on the day of elections, however, except a few mishaps, the elections proved fair and free. As an undemocratic tradition, some of the political parties claimed of rigging in some constituencies where the polls were allegedly manipulated and mismanaged.[27]

Ultimately, on May 11, 2013 poling was formally started in 69,729 polling stations across the county. According to the official sources 54.6 per cent registered voters casted their votes. However, Common Wealth Observer Mission, by impinging on the credibility of the electoral process, declared these elections free and fair. During $10^{\text {th }}$ Elections, in the political history of Pakistan, PML-N emerged the majority party with 124 general seats, PPPP got 31 while PTI could secure 27 National Assembly seats. In the meantime, 18 independent candidates joined the PML-N, enabling Nawaz Sharif to form his government, for the third time, without formulating an alliance with any other political party in the Parliament. Consequently, on June 7, 2013, he was sworn as the new Prime Minister of Pakistan. In this way a peaceful transition from one democratically elected government to the other has completed without any misshapes.[28] The development, no doubt, reflected political maturity of the political leadership and civil society.

\section{CONCLUSION}

Pakistani elections of 2013 elections can be called an historical event because for the first time in the country's history, a democratically elected government completed its five years term and a democratic transition took place from one elected government to another. Showing enough maturity, both PPP and PML-N signed COD in which they declared that democracy would be brought in the country at any cost. They have decided that neither any military based government would be joined nor be supported. If one party could formulate its government, the other will support it against anti-democratic forces and will never be tried to eliminate the ruling party from the government as it had frequently happened in the past.

Pakistan People's Party emerged as a majority party in 2008 Elections and formed a coalition government in the Centre as well as in the provinces. The PML-N, the second largest party in the Parliament was assigned to play a role of Opposition. However, contrary to expectations, on most of the occasions, People's Party consulted with coalition partners as well as opposition parties on major national issues. This policy of reconciliation resulted in an environment where the $18^{\text {th }}$ amendment passed unanimously in 2010 with the cooperation and coordination of all political stakeholders in the Parliament.

The amendment, withhold the powers of the President to dissolve the National Assembly and remove the Prime Minister, which had been given to the President by the $17^{\text {th }}$ Constitutional amendment passed by proMusharraf legislature. Similarly, the $19^{\text {th }}$ and $20^{\text {th }}$ Constitutional amendments were also passed during the PPP government. In point of fact, these amendments have brought a great development for the 2013 Elections. The caretaker government was selected with a complete consensus of major political parties of the country. Similarly, the office of the Chief Election Commissioner was also empowered in such a way that it could pave the way for a peaceful transition from one democratic government to other. PPP, after losing the elections, handed over the power to PML-N that has been emerged a majority party in the National Assembly. However, the rise and emergence of Pakistan Tehreek-e-Insaf (PTI) as a third major political force of Pakistan threatened the dynastic politics in Pakistan Similarly, there are many other challenges to the ruling PML-N government such as security, law and order situation, power shortage; however, the authorities are striving to address the situation accordingly. Yet the mutual consultation between PPP and PML-N leadership on every major issue is hopefully paving the way for a sustainable and viable democratic system in Pakistan.

\section{References}

[1]. Hasan Askari Rizvi, The Military and Politics in Pakistan: 1947-1986 (Lahore: Progressive Publisher, 1986 ), 186.

[2]. Peter R. Lovey, Asymmetric Warfare in South Asia: The Causes and Consequences of the Kargil Conflict (Cambridge: Cambridge University Press, 2009), 167-179.

[3]. Iffat Hamayun Khan, Electoral Mala-Practices during 2008 Election in Pakistan (Karachi: Oxford University Press, 2011 ), 21.

[4]. Pakistan: Transition to Democracy, Executive Summary and Recommendations, ICG Asia Report No.40 Islamabad/Brussels, available on www.crisisgroup.org > ... > Asia > South Asia > Pakistan (accessed on July 17, 2014).

[5]. Ibid.

[6]. Aslam Pervez Memon and Kiran Sami Memon, "Political Instability: A Case Study of Pakistan", Journal of Political Studies, 18, No.1 (2009): 31-34. 
[7]. Fahmida Mirza, “A Milestone in Pakistan's Parliamentary Democracy," The Parliamentarian Journal of the Parliaments of Commonwealth, issue one XCII (2011): 14-18.

[8]. Europe Union Observer Commission, Islamic Republic of Pakistan, European Union Election Observation Mission: Final Report National and Provincial Assemblies Elections 18 February, 2008, April 2008, 52-53.

[9]. Noor-Ul-Haq, “Transition to Democracy 2008," available on http://ipripak.org/factfiles/ ff96.pdf (accessed on July 19, 2014).

[10]. Dr. Fehmida Mirza was the first women Speaker of the National assembly of Pakistan. She was elected on March 19, 2008 as 19th Speaker of the National assembly. She has the distinction of being the 1st women Speaker in the Muslim World, For detail see National Assembly of Pakistan Proceedings, www.na.gov.pk, March 19, 2008. Also see for details Dr. Noor-Ul-Haq, "Transition to Democracy 2008," available on http:/ipripak.org/factfiles/ ff96.pdf (accessed on July 23, 2014).

[11]. Iffat Hamayun Khan, Electoral Mala-Practices during 2008 Election in Pakistan (Karachi: Oxford University Press, 2011 ), 21.

[12]. Noor-Ul-Haq, "Transition to Democracy 2008," available on http://ipripak.org/factfiles/ ff96.pdf (accessed on July 21, 2014).

[13]. National Assembly of Pakistan Proceedings, April 10, 2009; available on Official Website of National Assembly.

[14]. National Assembly of Pakistan, The Report on the Constitutional (Eighteenth) Amendment Bill 2010 (Islamabad: National Assembly of Pakistan, 2010), 4-5.

[15]. Ibid.

[16]. Mian Raza Rabbani, A Biography of Pakistani Federalism Unity in Diversity (Lahore: M/S Printing Press, 2011), 168-170.

[17]. Ibid.

[18]. Ibid.

[19]. Anwar Shah, "The 18th Constitutional Amendment: Glue or Solvent for Nation Building and Citizenship in Pakistan", The Lahore Journal of Economics 17 (September 2012): 387-391.

[20]. Amjad Abbas Magsi, "Balance of Power at the Centre: The President, Prime Minister \& Parliament," in Eighteenth Amendment Revisited, Maqsud Hasan Nori and Muhammad Hanif,ed. (Islamabad: Islamabad Policy Research Institute, 2011), 67-71.

[21]. Ahmad Bilal and Hamza Ijaz, "Challenges to Independence and Sovereignty of Parliament in Pakistan" IPRI Book, 68-70.

[22]. Daily Dawn, April 9, 2013.

[23]. Ibid.

[24]. Daily Jang, April 14, 2013

[25]. details, see Filling of Nomination Papers 25 to 31 March, Scrutiny of Nomination Papers 01 to 07 April, Appeal on ECP decision on Nomination Papers 08 to 10 April, Judgment on Appeal 16 April, Option for Withdraw all of Nominations 18 April, Final list of Candidates 19 April, Election National and Provincial Assemblies 11 May.

[26]. Ibid.

[27]. Ibid.

[28]. Ibid. 